А.В.Денисенко

магістр теології, магістр філософії, пошукач кафедри культурології

НПУ імені М.П.Драгоманова

\title{
РЕЦЕНЗІЯ НА КНИГУ
}

A Theology of Liberation. By Gustavo Gutierrez. Maryknoll, Orbis Books, 1988. XLVI+174 pp., ISBN 0-88344-542-5 (pbk.); \$18.60.

The subject of the new kind of theology which arose in 1960's and 1970 's been and still is much disputed issue. Here I mean liberation theology and the most influential book in this particular kind of theology, A Theology of Liberation by Gustavo Gutierrez. Time clamed this book as "The movement's most influential text.This book is a classical historical and theological study. It represents the new fresh wind in the history of theological study.

Gustavo Gutierrez (born 8 June 1928) is a Peruvian Roman Catholic theologian and priest who is often referred as the «father of liberation theology». He studied in Louvain and Lyons and after his graduation he came back to Peru, where he was a professor at the Catholic University in Lima at the same time, he has involved himself with the poor and has been a consultant to the Episcopal Conference of Latin America.

During a meeting in Petrópolis (Rio de Janeiro) with other Latin American theologians in Murch 1964, Gustavo Gutierrez described theology as "critical reflection on praxis. "As an idea, Gutierrez' theory was drawn from his lecture entitled "A Theology of Liberation", which had been delivered to a national meeting of lay persons, religious leadersand priests and was first published in Lima and then in Montevideo. Gutierrez' "new way of doing theology" was further developed at meetings in Havana, Bogotá, and Cuernavaca in June and July of 1965. Afterwards there were many other meetings that played a preparatory role for the Medellin conference of 1968. Therefore Gutierrez' lectures which he presented in Montreal in 1967 and at Chimbote in Peru on the poverty of the Third World and the challenge it posed to the development of a strategy of liberation were a further powerful stimulus toward a theology of liberation.Its outlines were first put forward at the theological congress at Cartigny, Switzerland, in 1969: "Toward a Theology of Liberation." 
Finally, in December 1971, Gustavo Gutiérrez published his fruitful work, Teología de la liberación. This book was a summarization of the pastoral political stances of the Medellin conference in Colombia, often known as CELAM II.

His theology includes Old Testament political interpretation of the Exodus and New Testament political interpretation of Jesus. According to Gutierrez, salvation cannot be seen in any kind of dualistic approach as distinguishable from liberation. Gutierrez believes that Marxist philosophy is not incompatible with Christian theology. He also believes that the established violence of Latin American dictatorships may, if necessary, be responded to by violence. His literature legacy includes: Theology of Liberation (1971, ET 1973) and We Drink from our Own Wells (1984).

The purpose of his book is to express the meaning and nature of liberation theology, to describe the reasons which gave birth to this new epoch in Latin America and to express this new challenge to injustice and dependence (p. xvii). In this Introduction Gutierrez defines that the term liberation theology as meaning "a critical reflection on the Christian praxis in the light of the Word of God." This definition is supported by Barth, who once said that "the true hearer of the word is the one who puts it into practice" (p. XXIX). Liberation theology, according to John Paul II (Letter to the bishops of Brazil, April 1986), is the "new stage... theological reflection that began with apostolic tradition and has continued in the great fathers and doctors..." (p. XLIV).

In his book Gutierrez uses the term liberation as better explanation of the meaning of the term development. In a new sense liberation can be understood as the single salvific process (p. XIV). Gutierrez opens his discussion with a question about the very meaning of Christianity and about the mission of the church (p. XIV).

The author starts his book with an explanation of some different ways of doing theology. According to the classical point of view, theology can be understood as wisdom (meditation on the Bible) or as rational knowledge. The first view was developed from the first century until the twelfth century. The second view was developed from the twelfth century and includes people like Thomas Aquinas, Albert the Great and Abelard. After that, Gutierrez shows that theology must be understood as critical reflection on practice. Actually this is not a new term. This kind of theology is based on the following theories, issues, events and persons (p. 6-8): charity, spirituality, anthropology, Maurice 
Blondel's new apologetics, the practical life of church, the teachings of Vatican II, the thoughts of Pope John XIII, philosophical issues of our time which show the necessity of active relationship with others, Marxist ideology, eschatological worldview and orthopraxis. In this case of a new understanding of the theological task, the church must deal with the real questions of the modern world and attempt to respond to them (p. 9). Theology as critical reflection on society and the Church leads to the pastoral action of the Church (10). Bouillard said that "A theology which is not up-to-date is false theology" (p. 10). Therefore, Gutierrez is dealing with new political hermeneutics of Gospel, which is the theology of liberation, theology of the future (p. 11) and a new way of doing theology (p. 12).

Gutierrez discusses the subject of the concept of development, which is opposite to the term "underdevelopment". This term presents two points of view: rich and poor, capitalism and socialism (p. 15). This term can be understood as a total social process and includes economics, social, political and cultural aspects (p.15). Gutierrez is trying to find a solution for the problem in which the poor underdevelopment is a product of the development of other countries (p. 17). In this case, the poor must participate in the social revolution and speak about economic, social and political liberation (p. 17). Liberation seems to be "from all that limits or keeps human beings from self-fulfillment" (p. 18).

The unjust circumstances give birth to social criticism. The task of this criticism is to deal with rich countries, which consider themselves central to humankind (p. 18). This issue returns us to Karl Marx who found the exploitation of persons in the capitalistic society as a social injustice (p.19). The answer to this injustice is the establishment of socialism (p. 20).

The other important point is correct understanding of different levels of the liberation process. Those levels are liberation of whole classes in economic and political sense (social level) and individual level of liberation (psychological level) (p. 20). In any case, the general idea of liberation is to be free from dependence (p. 22). This includes a proclamation of the new humanism (new humankind) and building the new world (qualitatively different society) (p. 22-23).

Gutierrez proofs his ideas from the Bible message (for freedom Christ has set us free (Gal. 5:1)). This leads to deepest understanding of the problem of sin, which includes rejection of God and neighbor (p. 24).

Author sees that the task of theology is to answer to the question, 
"What is relation between salvation and the historical process of human liberation" (p. 29). In this chapter the author shows that the theologian must deal with the relationships of faith and human existence, faith and social reality, faith and political action, Kingdom of God and human world. One of the tasks which the theologian must have is political responsibility (p. 30). The other task is to build a just and new society for the establishment of peace and justice among people (p. 31). To be Christian in this new sense is "to live solidarity, in faith, hope, and charity" (p. 32).

There are different responses to the question of the relationship between faith and present realities, between the church and the world ( $\mathrm{p}$. 34). Gutierrez shows those responses through history. He starts from Christendom mentality and continues until new Christendom. In this chapter readers can see how the church as a power in relation to the world has been profoundly modified during human history. It follows to conclude that man always searches for the just and democratic society (p. 36), for society, which is based upon justice, respect for the rights of others and human fellowship (p. 35). According to Gutierrez the task of the Kingdom of God is to provide the fellowship of the Church and world (p. 37).

Gutierrez is seeing the crisis on two levels. The first one is pastoral action and the second one is theological reflection. On the first level, he found necessity for the Christian community to return to the purely religious and spiritual function of the Church (p. 41). On the level of theological reflection, the author defines terms such as secularization, humanism and worldliness (p. 42). They are new challenges for the church of today and call for authentic relationship between humankind and nature, among human beings themselves, and between humankind and God (p. 42). At the end of this chapter and part Gutierrez shows that humankind has one call to salvation and thatto participate in the liberation process is already participation in the salvific work (p. 46).

Gutierrez shows that after a long process of oppression, dependence and regression, Latin America has gotten a new rebirth and awareness. Latin America has begun to move in the direction of modernization (p. 49-50). There he criticized capitalism, which is a form of imperialism and colonialism, and justified socialism as a more appropriate choice for society (p. 52). Gutierrez sees that the oppressor in this situation was the United States of America (p. 54). He claims to reject all kinds of oppressors by the use of social revolution (p.54-57).

Gutierrez shows that many theologians in Latin America started to 
commit themselves to the liberation process and many of them chose to radicalize their political options (p. 59). In this phase of the liberation process liberation theologians found appropriate dialogue with Marxism and started to use it as a good tool of crushing unjust society (p. 60). The issue of liberation of the poor took an important place at the Vatican II and at the Conference at Medellin, where bishops rediscovered their prophetical mission (p. 62). Liberation theology promoted new economy, new values, social transformation, new society and active participation in the life of the oppressed (p. 66-67).

In his book Gutierrez asks the following questions, such as "What is the meaning of faith?" and "How do you build a just society in harmony with values of the Kingdom?" He sees that Medellin's meeting was the beginning of a new relationship between "pastoral language" and the "social actions" (p.76). The author is calling Christians to learn to live and think of peace in conflict (p. 75). According to him, Latin Americans are moving to the new idea of the unity and community. It means that the Christian task is to "be in the world without being of the world. To be in the system without being of the system" (p. 76).

Gutierrez also discusses the relationship between salvation and the process of the human liberation throughout society. The main challenge here is to find connections between struggling against an unjust society and the creation of a new humanity. This is why he is asking himself what salvation is (p. 83).

The purpose of liberation theology for Gutierrez was to "create a new humanity." In this part of his book he is attempts to further develop this idea. The author sees that this purpose can be reach by understanding that humanity is the temple of God (p. 106-110). It means that God dwells everywhere and will be present in the very heart of every human being (p. 108). This axiom gives us a clear understanding that God is involved in human history (p.109). "The history is the living temple of God" (p. 110).

On the other hand, this particular purpose can be reached by rethinking our attitudes toward our neighbor. There one can find a call, which calls people to a close relationship with God and the neighbor (p. 110). To build a new society is to know God, but knowing God can be expressed only in the attempt to do justice for one's neighbor. There is a good verse in the Bible, which expresses this idea more clearly: "A man who sneers at the poor insults his maker" (Prov. 17:5). To love one's neighbors is to love Christ, because Christ is within the neighbor (p.112-116). 
The third thing which can help to someone to build a more just society is to know what real spirituality is. Real spirituality is "participation in the struggle for liberation of those oppressed by others." According to the Latin American context this is to participate in committing ourselves to the revolutionary process (p.117).

Gutierrez also talks about eschatology and politics as parts of liberation theology. Eschatological ideas are "the driving force" of liberation theology. This particular theology is very much based on eschatological themes. One can especially see that Gutierrez is drawing on ideas of Ernst Bloch's book The Hope Principle (p.123). In this chapter he also rethinks some other contemporary theologians of hope, such as Moltmann and Pannenberg (p.124). On the other side, ideas of hope also belong to Hegel, Feuerbach and Marx (p.125-126). This hope does not just believe in the future but rather is fulfilling the mobilizing and liberating function in history against injustice and trampled human rights (p.125).

The political dimension of the Gospel is another part of liberation theology. Gutierrez is taking Metz' political theology and rereading Jesus in the light of politics, His socio-political attitudes, and the relationship with Zealots (p.130-135). In this case the Church becomes an "institution of social criticism" and serves the liberation of (p.128).

In a context of Christian community and new society Gutierrez writes about connections between the ecclesiastical task and God's plan of salvation. According to Gutierrez, "all our ecclesiology will depend on the kind of relationship that we establish between the two" (p.143). "To call the church the visible sacrament of the saving unity is to define it in relation to the plan of salvation, whose fulfillment in history the church reveals and signifies to the human race" (p.147). Therefore the task of the church is the Eucharist, which means the memorial and thanksgiving (p. 148). The celebration of the liberation from Egypt and the Sinai Covenant is the real call of the new humankind (p.149). To be the Church is to take a clear position regarding the present state of social injustice and the revolutionary process (p.151). To preach the Good News is to announce the coming of the Kingdom which can be interpreted also as "feeling hunger of hungers" (p.153). In some ways, to proclaim the Kingdom is to take the side of oppression and criticize injustice in society, to struggle and to be in conflict with oppressors (p.156-161).

In his conclusion, Gutierrez is thinking about the term "poverty." He sees two kinds of poverty. The first is material and the second is 
spiritual (p.163-171). He comes to the logical conclusion that poverty on the one hand must be understood as solidarity with those who suffer and on the other hand as a protest against all those who exercise oppression (p.171-172).

Therefore it is true that $A$ Theology of Liberation was one of the most important and influential books of the $20^{\text {th }}$ century. This book was the answer to the situation which Gutierrez describes in the following way:

The people of Latin America have lived for a long time in ignorance of the realities of their own situation. Such ignorance applied still more to the underlying causes of the situation. Then they suffered from the obfuscations of "objective studies" made by and for those outside countries and economic groups that had interests in the subcontinent. ${ }^{1}$

Gutierrez in his book calls attention to the problem of the poor in Latin America and challenged the church to active participation in changing the economic and political systems that fostered social injustice.

Gutierrez's $A$ Theology of Liberation, now a classic, largely defined the continuing, worldwide discussion of liberation theology for more than a generation. His ideas informed Latin American, African American, Asian and Middle Eastern theologies, as well as those interested in issues related to feminism, racism, Third World development and economics, political freedom movements and poverty. ${ }^{2}$

As one could see in the Summarization, it discusses the main topics and issues which connect theology and social life. Some of the critics of liberation theology, such as Rhodes, see that Jesus' hermeneutics of the Old Testament knew nothing about putting praxis in the first place in the process of discovering theological truth. ${ }^{3}$ One must be careful in the attempting "to adapt the Gospel to our way of life, instead of adapting our way of life to the Gospel."4

One can find in Gutierrez' book the issue of European political theology and Marxism. Moltmann, in one of his articles, said that many people would like to see more information about Latin America in this

${ }^{1}$ G. Gutierrez, "Contestation in Latin America," in the Concilium, Volume 8, Number 7 (October 1971). - P.41.

2 L. James "Gustavo Gutierrez," in the Larry James' Urban Daily (Wednesday, January 18, 2006) Available at: http://larryjamesurbandaily.blogspot.com/2006/01/gustavogutierrez.html, Accessed on February 18, 2006.

3 Rhodes, "Christian Revolution in Latin America: The Changing Face of Liberation Theology," ResearchJournal, (Winter 1991). - P. 11.

${ }^{4}$ R. Padilla, "The Theology of Liberation," in Christianity Today, Volume XVIII, Number 3 (November 9, 1973). - P. 69. 
book, but instead they are seeing more about sociological theories of others, mostly western sociologists, than about the situation of injustice on the Latin American continent. ${ }^{1}$ Pannenberg, in his article "Christianity, Marxism, and Liberation Theology," also sees that many critics have objected to liberation theology's use of Marxism. They support the idea that affirms that Marxist categories cannot serve as a tool of social analysis without one's being drawn into its attendant atheistic view of history and humanity. Marxism's understanding of the economic causes of human alienation, for instance, cannot be separated from Marx's view of the human person as a product of one's own self-creation through work rather than as a creature of God. ${ }^{2}$

I want to summarize this book as a very influential book which changes theology and turns it in another direction. Millions of people in Latin America adopt this theology as the foundation of their worldview and mission strategies. One can fully agree with Larry James:

My discovery (of Gutierrez writings) turned out to be priceless. The Roman Catholic priest and theologian from Peru changed my heart and, then, my worldview forever. ${ }^{3}$

${ }^{1}$ J. Moltmann, „Open Letter to Jose Miguez Bonino,“ in Misson Trends. Liberation Theology, $N$ 4. Liberation Theologies. eds. G. Anderson; T. Stransky. Grand Rapids: Wm.B.Eerdmans Publishing Co., 1979. - P. 60.

2 W. Pannenberg, "Christianity, Marxism, and LiberationTheology," Christian Scholar's Review 18/3 (March 1989). - 215-226 p.

3 James "Gustavo Gutierrez". 